\title{
An Analysis of Shopping Center Investment
}

\author{
By: JOHN D. BENJAMIN, G. DONALD JUD, and DANIEL T. WINKLER
}

Benjamin, J. D., G. D. Jud, and D. T. Winkler. "An Analysis of Shopping Center Investment," Journal of Real Estate Finance and Economics, vol. 10, no. 2, March 1995, pp. 261-268.

Made available courtesy of Springer Verlag:

http://www.springer.com/economics/regional+science/journal/11146

\section{The original publication is available at www.springerlink.com}

****Note: Figures may be missing from this format of the document

\begin{abstract}
:
During the 1980s, the oversupply of retail space has lowered rents, raised vacancies, and damaged the integrity of financial institutions as developers and other borrowers have been forced into default. This paper explores the propensity of developers to create shopping center space. The research draws on the macroeconomic investment literature to formulate a model of shopping center investment. We estimate our model using shopping center and sales data from all fifty states of the United States and the District of Columbia. Our results provide evidence about how investment in new shopping space responds to changes in retail sales, capital costs, and taxes.

Key Words: Shopping centers, real estate investment, stock of retail space, construction lags, optimal level of space
\end{abstract}

\section{Article:}

The excessive overbuilding of retail space that has occurred in the United States in the 1980s suggests that investors, lenders, developers, and others would benefit from a better understanding of the dynamics of retail space creation. Recent history has shown clearly that errors made in responding to the changing nature of retail markets cannot be corrected easily or quickly. The fixity of retail space, the large amounts of capital required for construction or expansion, and the lags in the retail development process all act to inhibit rapid reallocations.

A number of prior studies in the economics, marketing, and geography literature have focused on retail location. Starting with Hotelling's (1929) classic article on duopoly location and Christaller's (1933) work on the spatial behavior of retailers, much of the literature has examined the location theories of central place, agglomeration economics, and demand externalities. ${ }^{1}$ This scholarly research has been critiqued by Eppli and Benjamin (1994), Ghosh, Craig, and McLafferty (1984), and Vandell and Carter (1993). Other researchers have explored the valuation of shopping centers and their leases (see, Eppli and Benjamin, 1994).

This paper differs from the existing literature by identifying the determinants of the supply of retail space. We draw on the macroeconomic investment literature to formulate a model of shopping center investment. Our model is estimated using cross-sectional shopping center data (the proxy for retail space) and retail sales data from the fifty states of the United States and the 
District of Columbia for the three years 1989-1991. This model reveals the response of shopping center investment to changes in retail sales. It also provides evidence on the impacts of capital costs and taxes. In the final section of the paper, we provide additional estimates of the model using aggregate national data for the period 1974-1992. Estimating the national model with a longer time series corroborates our results for the state level model.

\section{Previous Research}

When selecting areas for retail development, common rules of thumb would ask that developers compare sales per square foot of existing shopping center space with national averages or compare existing square feet of gross leasable area per household with national norms. ${ }^{2}$ If the sales per square foot are greater than the national average, for example, the extent of the difference is an indication of the area's capacity to sustain added retail space supply. These calculations help indicate whether an area is under- or overstored.

Some researchers focus on different guidelines for selecting sites for new retail development or expansion. Martin (1985) recommends that retail space investment be determined by expected sales, which in turn is estimated from potential market share and probable income growth. Developing a regression model that employs various economic and demographic variables, Whaley (1990), as another example, advocates that statistical analysis be used as a basis for estimating expected retail sales. He recommends that developers add retail space in those areas where expected sales estimates exceed actual sales. Benjamin, Jud, and Okoruwa (1994) utilize a distributed lag model developed by Koyck to show that lagged values of retail sales can be used to predict changes in retail space.

\section{Methodology}

Following the work of Jorgenson (1971) and others (see, for example, Wheaton and Torto, 1990), we assume that developers construct retail space such as shopping centers based on knowledge of the cost of capital and local tax rates along with some expectations of future sales volumes. Expectations of future sales are assumed to be based on the pattern of past sales. Thus, the desired stock of retail space $\left(\mathrm{K}^{*}\right)$ is assumed to be a function of lagged sales $\left(\mathrm{S}_{\mathrm{t}-\mathrm{n}}\right)$, the cost of capital $\left(\mathrm{r}_{\mathrm{t}}\right)$, and the local tax rate $\left(\mathrm{t}_{\mathrm{t}}\right)$ :

$$
\mathrm{K}_{\mathrm{t}}^{*}=\mathrm{K}\left(\mathrm{S}_{\mathrm{t}-\mathrm{n}}, \mathrm{r}_{\mathrm{t}}, \mathrm{t}_{\mathrm{t}}\right) \text {. }
$$

Because there are substantial adjustment costs in the development process and because these costs can be expected to rise with the speed of adjustment, developers often will not want to move quickly from the actual level of space $\left(\mathrm{K}_{\mathrm{t}}\right)$ to their desired level. Instead, they are likely to spread the development over some period of time. Thus, the actual level of investment $\left(\mathrm{I}_{\mathrm{t}}\right)$ in any period is determined by an adjustment parameter $\mathrm{v}$ that reflects how quickly developers want to move from the actual to the desired level of space:

$$
\mathbf{I}_{\mathrm{t}}=\mathrm{v}\left(\mathrm{K}_{\mathrm{t}}^{*}-\mathrm{K}_{\mathrm{t}}\right) \text {. }
$$

The model for retail space investment is derived by substituting equation 1 into equation 2 :

$$
I_{t}=v\left(a_{0}+a_{1} S_{t-n}+a_{2} r_{t}+a_{3} t_{t}\right)-v K_{t-1} \text {. }
$$


From equation 3, the coefficient of the lagged sales variable is expected to be positive while the coefficients for the cost of capital, tax rate, and lagged actual space are anticipated to be negative.

Estimates of the model provide insights into the nature of the lags in the development process. For example, how long does it take a change in the desired capital stock to be translated into additional space? For developers, lenders, and other retail market participants anticipating capacity expansions, the answer to this question has important implications. It is found in the estimates of $\mathrm{v}$ : the smaller $\mathrm{v}$ is, the more extended the adjustment process. The mean lag of the adjustment process can be shown to be $(1-\mathrm{v}) / \mathrm{v} .{ }^{3}$ So, for example, if $\mathrm{v}$ is 0.25 , the mean lag would be 3 , indicating that in three years, one-half of the difference between the desired and actual capital stock will be translated into additional space.

The long-run solution to the model provides an estimate of the optimal level of space for any particular level of sales. This long-run solution occurs where investment equals zero because then the desired capital stock equals the actual capital stock. From equation 3, the long-run solution is

$$
\mathrm{K}=\mathrm{A}_{0}+\mathrm{A}_{1} \mathrm{~S}+\mathrm{A}_{2} \mathrm{r}+\mathrm{A}_{3} \mathrm{t} \text {. }
$$

Equation 4 reveals the level of shopping space that is consistent with any level of sales, given the cost of capital and the tax rate. This long-run solution, thus, shows a method of estimating whether retail trade areas are over- or understored given the expected growth in sales.

The tax rate variable in equations 3 and 4 is the effective rate of taxation on real estate income in the state in which the shopping center is located. Numerous studies have examined the impact of state and local taxes on growth and investment. For a review of the early literature, see Plaut and Plata (1983). Two more recent studies by Helms (1985) and McDonald (1993) provide some additional insight into the impact of state and local taxes on economic activity. Helms reports that state and local taxes have little impact on growth and investment except when tax revenues are used to fund transfer payments. When tax revenues are used to pay for public services and infrastructure, Helms reports that the effect is neutral or even positive. McDonald, examining the effects of local property tax rates in the Chicago area on changes in the growth of business real estate values, finds that increases in the property tax rate are negatively associated with the appreciation of real estate market values.

\section{Data and Estimated Results}

Sample data to estimate equation 3 include observations for each of the fifty states and the District of Columbia for the years 1989 through 1991. We employ the total shopping center space located in each state as a proxy for that state's total retail space. The data are gathered from two sources. Information on shopping center gross leasable area is obtained from The Scope of the Shopping Center Industry in the United States published by the International Council of Shopping Centers (ICSC). ${ }^{4}$ Annual retail sales data are provided by various U.S. Census Bureau Reports. Other data on capital costs, interest rates, and taxes are obtained from official published sources such as the Federal Reserve Bulletin. 
Table 1 shows the means and standard deviations of the variables included for the state data series. $1_{\mathrm{s}, \mathrm{t}}$ and $\mathrm{K}_{\mathrm{s}, \mathrm{t}-1}$ are measured in square feet of shopping center space. $\mathrm{S}_{\mathrm{s}, \mathrm{t}-1}$ reflects retail sales in inflation-adjusted dollars as deflated by the CPI. The cost of capital $\left(\mathrm{r}_{\mathrm{t}}\right)$ is measured by the real rate on long-term government bonds. The tax rate $\left(t_{s, t}\right)$ is measured in two alternative ways: 1$)$ the total tax rate in the state $\left(\operatorname{tr}_{\mathrm{s}, \mathrm{t}}\right)$ which is total state and local taxes as a fraction of state personal income and 2) the average property tax rate in the state $\left(\mathrm{pr}_{\mathrm{s}, \mathrm{t}}\right)$, which is total property taxes as a fraction of state personal income. ${ }^{5}$

The empirical model used to estimate equation (3) is

$$
I_{s, t}=b_{0}+b_{1} S_{s, t-1}+b_{2} r_{t}+b_{3} t_{s, t}+b_{4} K_{s, t-1}+b_{5} S T_{s}+e_{s, t}
$$

where $\mathrm{ST}_{\mathrm{S}}$ is a shift parameter for each state. ${ }^{6} \mathrm{ST}_{\mathrm{s}}$ allows for the existence of state-specific characteristics (such as topographical conditions, quantity and quality of arable and habitable land, zoning laws, and so on).

The empirical estimates of the investment model are shown in Table 2.7 The first two columns of Table 2 show the OLS estimates that are obtained without including the vector of fixed state effects (ST) in the model. Columns 3 and 4 of Table 2 show the estimates produced when the state effects are included. Comparison of the two sets of estimates reveals

Table 1. Variable means and standard deviations.

\begin{tabular}{lcc}
\hline \multicolumn{1}{c}{ State Data } & Mean & Standard Deviation \\
\hline $\mathrm{I}_{\mathrm{s}, \mathrm{t}}$ (in millions) & 1.7 & 2.6 \\
$\mathrm{~S}_{\mathrm{s}, \mathrm{t}-1}$ (in \$ billions) & 10.8 & 12.3 \\
$\mathrm{~K}_{\mathrm{s}, \mathrm{t}-1}$ (in millions) & 82.0 & 92.4 \\
$\mathrm{r}_{\mathrm{t}}$ (percent) & 3.4 & 0.2 \\
$\mathrm{tr}_{\mathrm{s}, \mathrm{t}}$ (percent) & 10.3 & 1.8 \\
$\mathrm{pr}_{\mathrm{s}, \mathrm{t}}$ (percent) & 3.1 & 1.2 \\
$\mathrm{n}$ & 153 & \\
\hline \multicolumn{1}{c}{ National Data } & Mean & 37.2 \\
\hline $\mathrm{I}_{\mathrm{t}}$ (in millions) & 131.1 & 9.3 \\
$\mathrm{~S}_{\mathrm{t}-1}$ (in \$ billions) & 103.1 & 717.7 \\
$\mathrm{~K}_{\mathrm{t}-1}$ (in millions) & $7,190.2$ & 1.9 \\
$\mathrm{r}_{\mathrm{t}}$ (percent) & 9.1 & 0.7 \\
$\operatorname{tax}_{\mathrm{t}}$ (percent) & 33.7 & \\
$\mathrm{n}$ & 19 & Standard Deviation \\
\hline
\end{tabular}


Table 2. Shopping center investment (t-values in parentheses).

\begin{tabular}{lcccc}
\hline & $(1)$ & $(2)$ & $(3)$ & $(4)$ \\
& OLS & OLS & Fixed Effects & Fixed Effects \\
\hline Constant & -1.312 & -1.834 & 30.072 & 31.432 \\
& $(-0.85)$ & $(-1.26)$ & $(2.57)$ & $(2.67)$ \\
$\mathrm{S}_{\mathrm{s}, \mathrm{t}-1}$ & 0.640 & 0.638 & 0.924 & 0.877 \\
& $(8.14)$ & $(8.10)$ & $(4.48)$ & $(4.11)$ \\
$\mathrm{r}_{\mathrm{t}}$ & 0.550 & 0.556 & -0.098 & -0.092 \\
& $(1.34)$ & $(1.35)$ & $(-0.38)$ & $(-0.36)$ \\
$\mathrm{tr}_{\mathrm{s}, \mathrm{t}}$ & -0.068 & - & -0.263 & - \\
& $(-1.19)$ & & $(-1.04)$ & -0.576 \\
$\mathrm{pr}_{\mathrm{s}, \mathrm{t}}$ & - & -0.067 & - & $(-1.24)$ \\
& & $(-0.77)$ & -0.157 \\
$\mathrm{~K}_{\mathrm{s}, \mathrm{t}-1}$ & -0.062 & -0.061 & $-10.91)$ & $(-10.81)$ \\
& $(-5.92)$ & $(-5.87)$ & 0.918 & 0.919 \\
\hline
\end{tabular}

clearly that the fixed state effects are very important. The F-value for the joint test of significance of the state effects vector is 6.34, significant at the .01 level. When we focus on columns 3 and 4 of Table 2 and examine the estimates with fixed state effects, all the coefficients of the model appear with their expected signs.

As expected, $\mathrm{v}$ representing the estimated coefficient on $\mathrm{K}_{\mathrm{s}, \mathrm{t}-1}$, is small. Because $\mathrm{v}$ is small, the adjustment from actual to desired capital stock is very slow. This result corroborates the existence of substantial lags in the construction of new shopping space. That the estimated value of $\mathrm{v}$ in column 3 of Table 2 is equal to 0.159 suggests a mean lag of 5.3 years. The long lags in the adjustment of space suggest prolonged cycles in shopping space construction, a situation that may help explain how the recent space glut was produced.

Both the cost of capital and the tax variables have the expected negative signs, but neither is statistically significant. This lack of significance for the cost of capital variable can be attributed to the shortness of the time series and the resulting lack of variation in the sample data. It seems reasonable to assume that a sample with greater variation for this variable would provide evidence of more substantial effects.

Our finding of a weak statistical association between state and local taxes and shopping center investment corroborates the preponderance of findings reported in the literature that individual state and local taxes have a relative marginal impact on investment when compared with the factors of market size and growth (Plaut and Pluta, 1983). ${ }^{8}$ Nevertheless, we believe that the subject of the effect of state and local taxes on shopping center investment is a matter that merits additional attention and further research. ${ }^{9}$

\section{Estimates Using National Time-Series Data}

Because the state data used in the previous section have become available only in the last four years, this short time series makes it impossible to estimate separate models for each state. Available from F.W. Dodge beginning in 1970, however, is a national time series, showing the aggregate number of square feet of retail space (excluding restaurants). ${ }^{10}$ Estimates using the 
national data series provide a further test of the validity of the model set forth in the previous section. Descriptive statistics for the national data series are presented in Table 1.

Using the national data for 1974-1992, the following results are obtained (t-values in parenthesis):

$$
\begin{aligned}
& \mathrm{I}_{\mathrm{t}}=26.78+6.54 * \mathrm{~S}_{\mathrm{t}-1}+2.06 * \mathrm{r}_{\mathrm{t}}-3.13 * \operatorname{tax}_{\mathrm{t}}-0.065 * \mathrm{~K}_{\mathrm{t}-1} \text {. } \\
& \begin{array}{llll}
(0.13) \quad(3.70) \quad(0.88) & (0.52) \quad(2.42)
\end{array} \\
& \text { Adj } R^{2}=0.86 \text { D.W. }=1.91 \quad \mathrm{n}=19
\end{aligned}
$$

The model is estimated using the Cochrane-Orcutt technique for autoregressive correction. The tax variable $\left(\operatorname{tax}_{t}\right)$ is defined as total taxes as a fraction of personal income. Other versions of the tax variable, including state and local taxes as a fraction of personal income $\left(\operatorname{tr}_{t}\right)$, indicated little change in the relative impact of taxes.

Results from the estimated national model support the results presented in Table 2: lagged sales and capital stock are shown to be the dominant variables in explaining shopping center investment. The estimated value of the coefficient on lagged capital stock $\left(\mathrm{K}_{\mathrm{t}-1}\right)$, which represents the speed of adjustment $(\mathrm{v})$ is again found to be very small. Taxes and capital costs appear to exert relatively little statistical influence.

The long-run solution of the model shown in equation 4 provides a way to calculate the desired stock of retail space $\left(\mathrm{K}^{*}\right)$ given the current level of sales, taxes, and interest rates. Computing the ratio of the actual stock of space $\left(\mathrm{K}_{\mathrm{t}}\right)$ to the desired stock $\left(\mathrm{K}^{*}\right)$ provides an "index of shopping space supply." Using the estimated national model shown above and the current values for all variables yields a ratio of 0.82 . The index suggests that, given the 1992 level of sales, actual space was 22 percent smaller than desired space in 1992.

\section{Conclusions}

This paper examines the propensity of developers to create shopping center space. Drawing on the macroeconomic investment literature, the paper formulates a model of shopping center investment. Estimates of the model, derived using shopping center and sales data from all fifty states of the United States and the District of Columbia, provide evidence on how investment in new shopping space responds to changes in retail sales, capital costs, and state and taxes.

The model reveals that adjustments by developers in response to changes in sales, capital costs, and taxes are very slow. Empirical estimates suggest an average lag of 5.3 years. The long lags in the adjustment of shopping center space suggest prolonged cycles in retail space construction which may help explain how the early 1990s glut of space occurred.

The estimated investment model suggests that changes in retail sales are overwhelmingly the most important factor driving shopping center investment. While investment appears to respond to variations in capital costs and taxes in the anticipated manner, their statistical associations are weak.

\section{Acknowledgments}


The authors gratefully acknowledge the research support provided by the Real Estate Research Institute (Bloomington, IN) and the International Council of Shopping Centers. They also are indebted to Peter Chinloy, John Konarski III, and an anonymous referee for helpful comments and suggestions.

\section{Notes}

1. Central place theory examines the connection between retail location and town situs. Retail agglomeration economics stress that retail locations developed from comparison shopping, Retail demand externalities are created when anchor tenants draw shoppers to retail sites so as to provide traffic for smaller tenants. See Eppli and Benjamin (1994) for further discussion.

2. As an example, Trachtenberg (1990) reports that a typical rule of thumb is that a market is saturated when it has 12 or more square feet of retail space per household.

3. See Pindyck and Rubinfeld (1981), page 233.

4. ICSC defines a shopping center as

A group of architecturally unified commercial establishments built on a site which is planned, developed, owned, and managed as an operating unit related in its location, size, and type of shops to the trade area that it serves. The unit provides on-site parking in definite relation to the type and total size of stores.

5. We also examined the tax effect using state sales taxes as a percent of personal income. As with the other specifications of the tax variable, we found no consistent statistical association between sales tax rates and shopping center investment.

6. A vector of time-specific dummy variables was included in preliminary estimates of the model. This set of time dummy variables was intended to capture nationwide timespecific economic factor such as secular growth and the business cycle; population trends; federal, fiscal, and monetary policy; and other factors. Analysis revealed that the vector of time dummy variables was statistically insignificant at the 5-percent confidence level. The F-value for the joint test of significance was 3.23. Accordingly, the vector of time variables was dropped in the subsequent analysis. In addition, the estimated autocorrelation of $\mathrm{e}(\mathrm{i}, \mathrm{t})$ residuals was approximately zero; therefore, the removal of autocorrelation from the time series residuals for each cross-sectional unit was not necessary.

7. The GLM and REG Procedures in SAS and fixed factor and random effects regression models in LIMDEP 6.0 provides the econometric software for use in this study.

8. Although equation 5 assumes a common slope coefficient for the tax variable for all states, it is possible to estimate individual slope coefficients for the tax rate variables by state using an interaction term of the state shift parameters and tax rate for each state. A Chow test comparing equation 5 with the proposed specification leads to conflicting findings. For the total state tax rate variable, the F-value is 1.96 and is significant at the .05 level, while for the property tax variable, the F-Value is 1.37 and is not significant at .05 .

9. Setting aside the question of statistical significance for the moment, the elasticity coefficients of the tax variables when calculated at the sample means with the fixedeffects models are -1.561 and -1.034 for the total tax rate and property tax rate 
variables, respectively. These elasticity estimates suggest that shopping center investment is elastic with respect to changes in state and local taxes.

10. We are indebted to the International Council of Shopping Centers for support in obtaining the national data series.

\section{References}

Benjamin, John D., G. Donald Jud, and A. Ason Okoruwa. (1994). "Forecasting the Stock of Retail Space Using the Koyck Distributed Lag Model," Journal of Property Research (forthcoming).

Brown, Stephen. (1989). "Retail Location Theory: The Legacy of Harold Hotelling," Journal of Retailing 65:4 (Winter), 451-470.

Christaller, W. (1933). Die Zentralen Orte in Suddeutschland. Germany: G. Fischer.

Ghosh, A., C.S. Craig, and S.L. McLafferty. (1984). "Models of the Retail Location Process: A Review," Journal of Retailing 60:1 (Spring), 5-36.

Eppli, Mark J. and John D. Benjamin. (1994). "The Evolution of Shopping Center Research: A Review and Analysis," Journal of Real Estate Research 9:1 (Winter), 5-32.

Eppli, Mark J. and James D. Shilling (1995). "Speed of Adjustment in Commercial Real Estate Markets," Southern Economic Journal (forthcoming).

Gujarati, Damodar N. (1988). Basic Econometrics (2nd edition). New York: McGraw-Hill Book Company, pp. 505-534.

Helms, L. Jay. (1985). "The Effect of State and Local Taxes on Economic Growth: A Time Series-Cross Section Approach," Review of Economics and Statistics 67:4 (Nov.), 574-582. Hotelling, Harold. (1929). "Stability in Competition," Economic Journal 39:3, 41-57.

Ingene, Charles A. and Eden S.H. Yu. (1981). "Determinants of Retail Sales in SMSAs," Regional Science and Urban Economics 11, 529-547.

Jorgenson, Dale W. (1971). "Econometric Studies of Investment Behavior: A Survey," Journal of Economic Literature 9:4, 1111-1147.

Koyck, L.M. (1954). Distributed Lags and Investment Analysis. Amsterdam: North-Holland Publishing Company. Martin, W.B. (1985). "Estimating Retail Sales Potential for a Proposed. Regional Shopping Center," Real Estate Review 15:2 (Summer), 77-81.

McDonald, John F. (1993). "Local Property Tax Differences and Business Real Estate Values,"

The Journal of Real Estate Finance and Economics 6:3 (May), 277-287.

National Research Bureau. "Shopping Center Directory-The South." Chicago, (various volumes).

Pindyck, Robert S. and Daniel L. Rubinfeld. (1981). Econometric Models and Economic

Forecasts. New York: McGraw-Hill.

Plaut, Thomas R. and Joseph E. Pluta. (1983). "Business Climate, Taxes and Expenditures, and State Industrial Growth in the United States," Southern Economic Journal 50:1 (July), 99-119. Trachtenberg, Jeffrey A., (1990). "Largest of All Malls in the U.S. Is a Gamble in Bloomington, Minn." Wall Street Journal (October 30), 1.

Vandell, Kerry D., and Charles C. Carter. (1993). "Retail Store Location and Market Analysis: A Review of the Research," Journal of Real Estate Literature 1 (January), 13-45.

Whaley, John W. (1990). "Scanning for Retail Development Opportunities," Real Estate Review 19:4 (Winter), 43-49. Wheaton, William C. and Raymond G. Torto. (1990). "An Investment Model of the Demand and Supply for Industrial Real Estate," AREUEA Journal 18:4 (Winter), 530-547. 